\title{
ДОСЛІДЖЕННЯ МІКРОХВИЛЬОВОГО ВАКУУМ-ВИПАРНОГО МОДУЛЯ БЕЗПЕРЕРВНОЇ ДІї
}

\author{
Сиротюк I.B., аспірант \\ Одеська національна академія харчових технологій, м. Одеса, Україна
}

Проведено аналіз досліджень впливу мікрохвильових технологій на прочес випаровування. Виділено основні переваги застосування електромагнітного впливу на сировину при випаровуванні поряд з традиційними технологіями концентрування харчових розчинів.

Висвітлено один з головних недоліків існуючих дослідних стендів випарних апаратів з електромагнітним підведенням енергії, а саме періодичність дії. Визначено основні проблеми, шуо перешкоджають організачії прочесу випарювання в безперервному режимі в умовах об'ємного підведення енергії і вакууму.

На основі аналізу ичих проблем запропонована конструкція мікрохвильового вакуум-випарного модуля, яка дозволяє забезпечити безперервний режим роботи без порушення герметичності системи і при відсутності витоку мікрохвильового поля протягом усього процесу концентрування.

Головне завдання даної роботи полягає в проведенні експериментальних досліджень розробленого модуля в умовах безперервної роботи. Досліди проводилися на прикладі иукрового розчину.

Концентрачії початкової сировини, що поступала до модуля, і готового продукту, щчо вивантажувався, протягом усього процесу становили $30^{\circ} \mathrm{brix}$ i 40-42 하 відповідно. Тиск в системі в ході випробувань модуля залишався незмінним і знаходився в межах 0,01 МПа.

На основі отриманих результатів експериментальних досліджень можна стверджувати про працездатність розглянутої конструкиї мікрохвильового вакуум-випарного модуля безперервної дії і про можливість проектування і реалізації його напівпромислового зразка.

За допомогою застосування методу компонування таких модулів надається можливість сконструювати багатоступеневу випарну установку, щзо в свою чергу дозволяє отримати готовий продукт будь-якої кінцевої концентрації сухих речовин без втрати якості. Крім того, подібна конструкція відрізняється достатньою легкістю в обслуговуванні через незалежність кожного модуля.

Ключові слова: випарювання, концентрування, мікрохвильові технології, моделювання, тепломасообмiн.

\section{Встуі}

Вимоги сучасного суспільства до якості готового продукту неухильно ростуть. Поряд 3 постійним збільшенням темпу життя підвищується попит на готові до вживання харчові концентрати, що володіють високим вмістом вітамінів та інших корисних компонентів, необхідних для задоволення максимально можливої кількості поживних потреб організму людини [1-3]. Одними 3 найбільш вживаних продуктів харчоконцентратного виробництва $€$ концентрати фруктових і овочевих соків [4-6]. Вищевказані якісні показники готового продукту безпосередньо залежать від технології їх отримання. Крім того, варіативність процесів концентрування обумовлює і різні рівні споживання енергоресурсів, що в свою чергу суттєво позначається на собівартості соків.

Аналіз літературних джерел та формулювання проблеми

Серед існуючих методів концентрування харчових розчинів найбільш поширеним є випарювання, що забезпечує отримання якісного харчового концентрату при відносно невисоких витратах на обладнання [7, 8]. Досить високу популярність набирають дослідження даного процесу з використанням мікрохвильових (MB) технологій на прикладі різних фруктових і овочевих соків: ананасу [9, 10], яблука [11], кокосу [12], гранату, винограду, моркви [13]. Подібний науковий ажіотаж обумовлюється високими якісними показниками готового продукту, оскільки при електромагнітному підводі енергії відсутня класична теплопередача, що в свою чергу унеможливлює утворення прикордонного шару i, як наслідок, продукт не набуває присмаку варіння. Також, вищевказаний принцип нагріву дозволяє отримати в процесі випарювання абсолютно тверду фазу, що практично неможливо в традиційних випарних установках [14].

Однак, узагальнюючи результати, висвітлені в вищевказаних зарубіжних статтях, можна з упевненістю сказати, що представлені інноваційні випарні апарати не можуть бути використані на харчових підприємствах через малий об’єм сировини, що завантажується, відсутності вакууму і, в кінцевому підсумку, через роботу в режимі періодичної дії. Установки даного типу зумовлюють виникнення певних проблем в умовах тоннажного виробництва, оскільки харчоконцентратні підприємства більшою мірою характеризуються се- 
зонною роботою, перерви якої викликані вивантаженням продукту і завантаженням сировини є неприйнятними. Організація безперервного режиму концентрування харчових розчинів за допомогою об'ємного підведення енергії в умовах вакууму є досить складним завданням. Під загрозою недотримання виявляється цілий ряд обов'язкових умов безпечної та якісної роботи системи: герметичність, ізоляція МВ поля, узгодження безперервної подачі сировини з вивантаженням готового продукту і пароутворенням. В результаті аналізу вищевказаних проблем в ОНАХТ була розроблена конструкція мікрохвильового вакуум-випарного модуля безперервної дії, який має досить високу герметичність і при належному рівні заповнення сировиною абсолютно виключає витік електромагнітного випромінювання. У даній роботі була поставлена задача провести експериментальні дослідження, що підтверджують працездатність такого модуля в режимі безперервної роботи.

\section{Модель інноваційного модуля}

Основою запропонованої конструкції модуля (рис. 1) є циліндричний корпус (3) виготовлений з радіонепроникного металу. У корпусі є спеціальне вікно для магнетрона (6), мікрохвильова енергія якого впливає на сировину через Радіопрозорий корпус (5), виконаний з тефлону. 3 торцевих частин корпусу за допомогою шпильок (4) приєднані верхній (2) і нижній (7) фланці. Верхній фланець обладнаний патрубком (1) для відкачування повітря перед початком процесу випарювання, а також для виходу вторинної пари. У нижньому фланці є патрубки для безперервної подачі сировини (8) і безперервної вивантаження готового продукту (9).

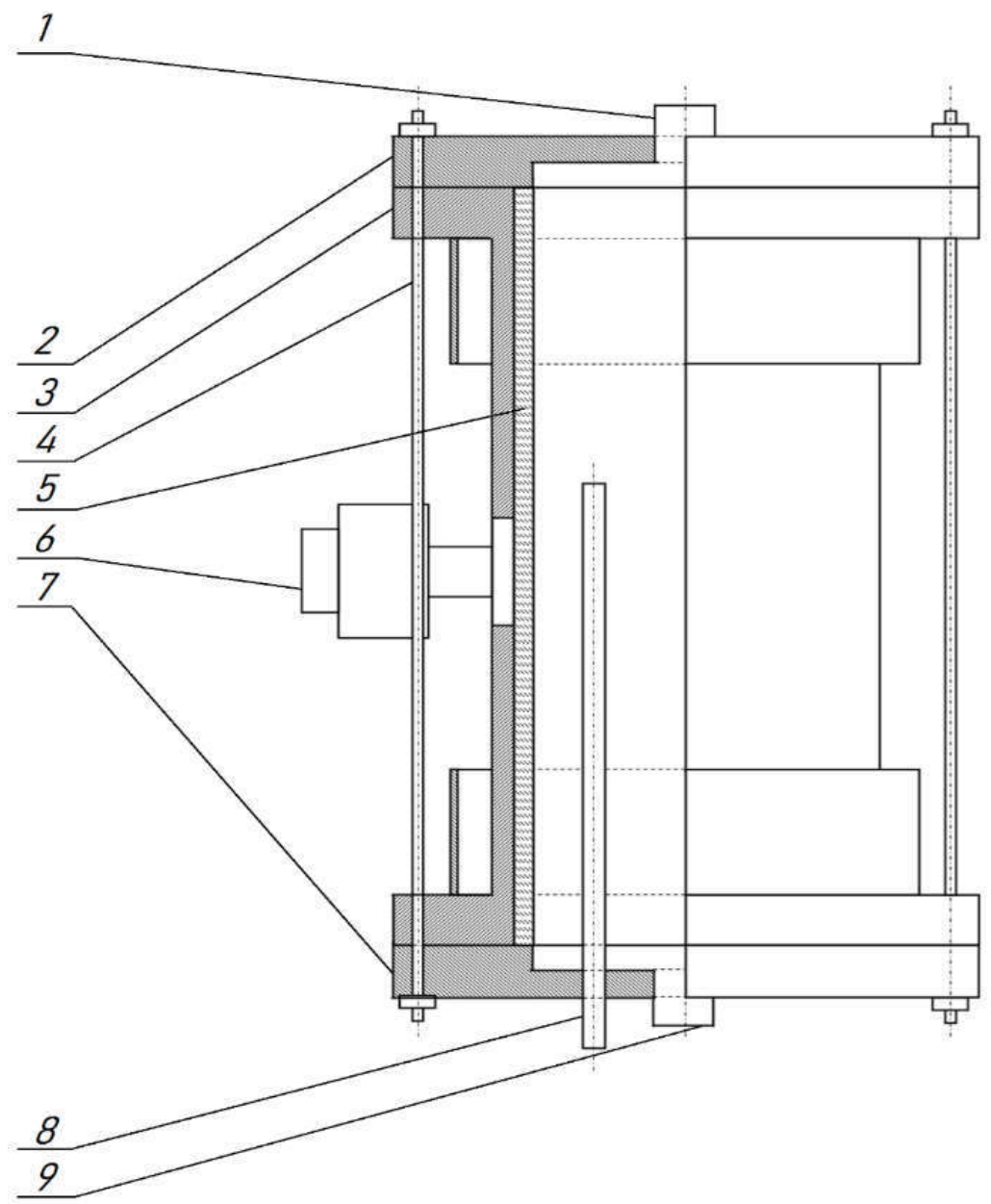

Рис. 1 - Схема запропонованої конструкції мікрохвильового вакуум-випарного модуля

Основними елементами експериментального стенду (рис. 2) є: ємність вихідного продукту (1), реакційний об'єм (2), вакуум-насос (ВН), конденсатор (4), водоохолоджувач (BО), збірник конденсату (5) і вимірювально-обчислювальний комплекс (ВОК). 


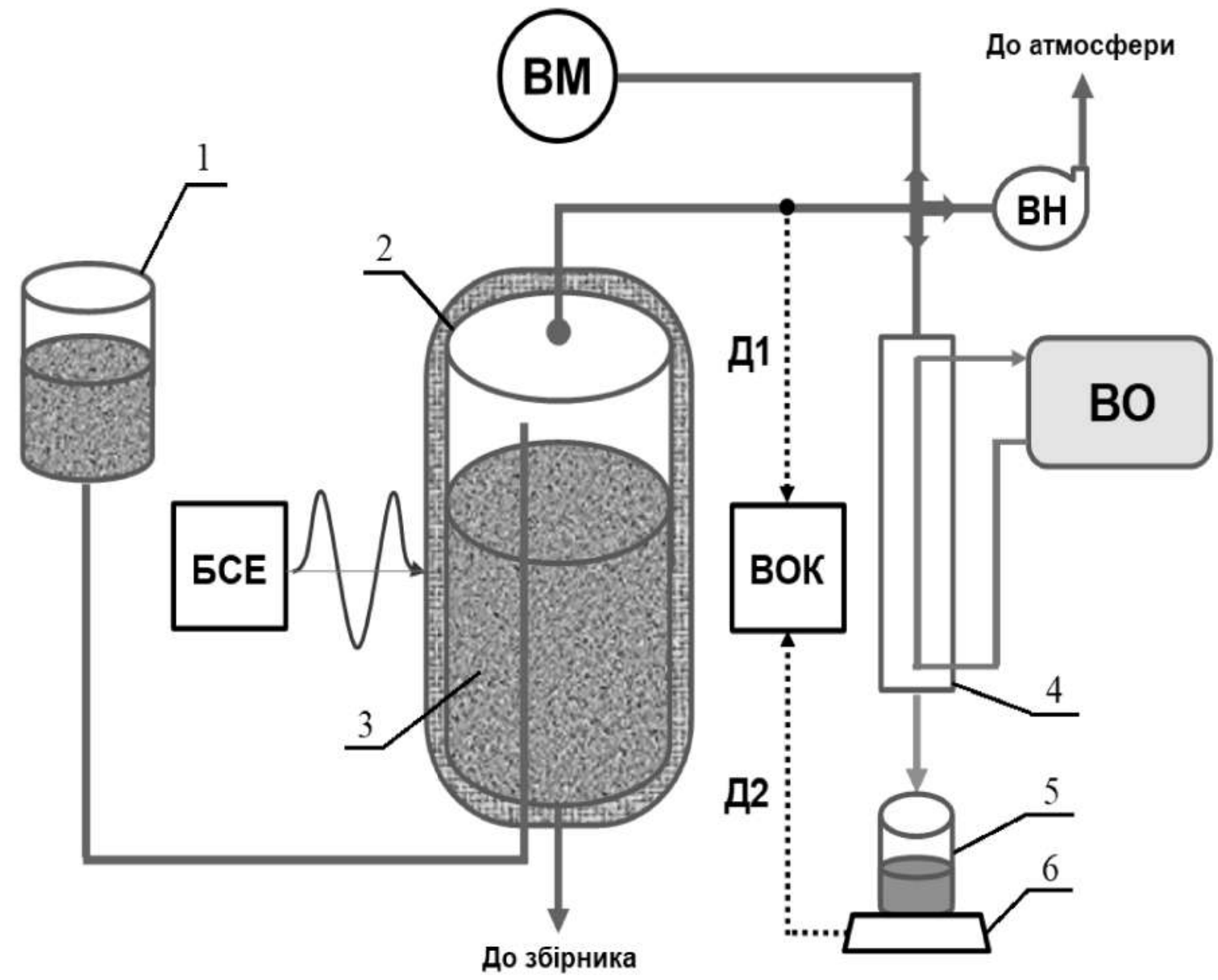

1 - ємність початкового продукту, 2 - реакційний об' $є$ м, 2 - продукт, 4 - конденсатор, 5 - збірник конденсату, 6-ваги, ВМ - вакуумметр, ВН - вакуум-насос, ВО-водоохолоджувач, БСЕ - блок силової електроніки, ВОК - вимірювально-обчислювальний комплекс, Д1 - сигнал температури пари, Д2 - сигнал електронних ваг.

\section{Рис. 2 - Схема експериментального стенду для дослідження МХ вакуум-випарного модуля}

Реакційний обсяг за допомогою паропроводу з'єднаний з конденсатором. Контроль вакууму в системі здійснюється за допомогою зразкового вакуумметра. Блок силової електроніки за сигналами блоку управління, що складається з регулятора потужності і таймера, організовує підведення електромагнітної енергії до продукту. Водоохолоджувач працює за таким же принципом, як і в схемі з МВ ВВУ періодичної дії [15]. Поточні показання вимірювача температури пари на виході (Д1) і електронних ваг (6) через інтерфейс надходять на процесор ВОК для подальшої обробки. В якості вимірювальних приладів були використані: електронні ваги TBE-0,21-0,01 і датчик температури Dallas DS 18b20. Збір інформації здійснювався за допомогою планшета CHUWI CW1506. Програма реєстрації та обробки даних була реалізована на базі SCADAсистеми Simp Light.

\section{Випробування модуля в режимі безперервної роботи}

Режим безперервної роботи є ефективним для умов тоннажного виробництва. Дослідження проводилися при рівні потужності, що підводиться, в 600 Вт і мінімальному тиску (10 кПа). В якості вихідної сировини був використаний цукровий розчин з початковою концентрацією $30^{\circ}$ brix. Протягом всього процесу підтримувався постійний рівень продукту 2,2 л.

Вирішення поставленого завдання лежить у чіткому узгодженні матеріальних потоків: надходження сировини дорівнює сумі потоків готового продукту і конденсату.

Циклічне надходження сировини і відведення концентрату є допустимим за умови безперервного відведення та конденсації парів розчинника. Оптимізація управління цими процесами $є$ самостійною задачею, як в теоретичному аспекті, так і при технічній реалізації системи такого регулювання. Представлені залежності (рис. 3,4 ) отримані при ручному регулюванні витрат. 


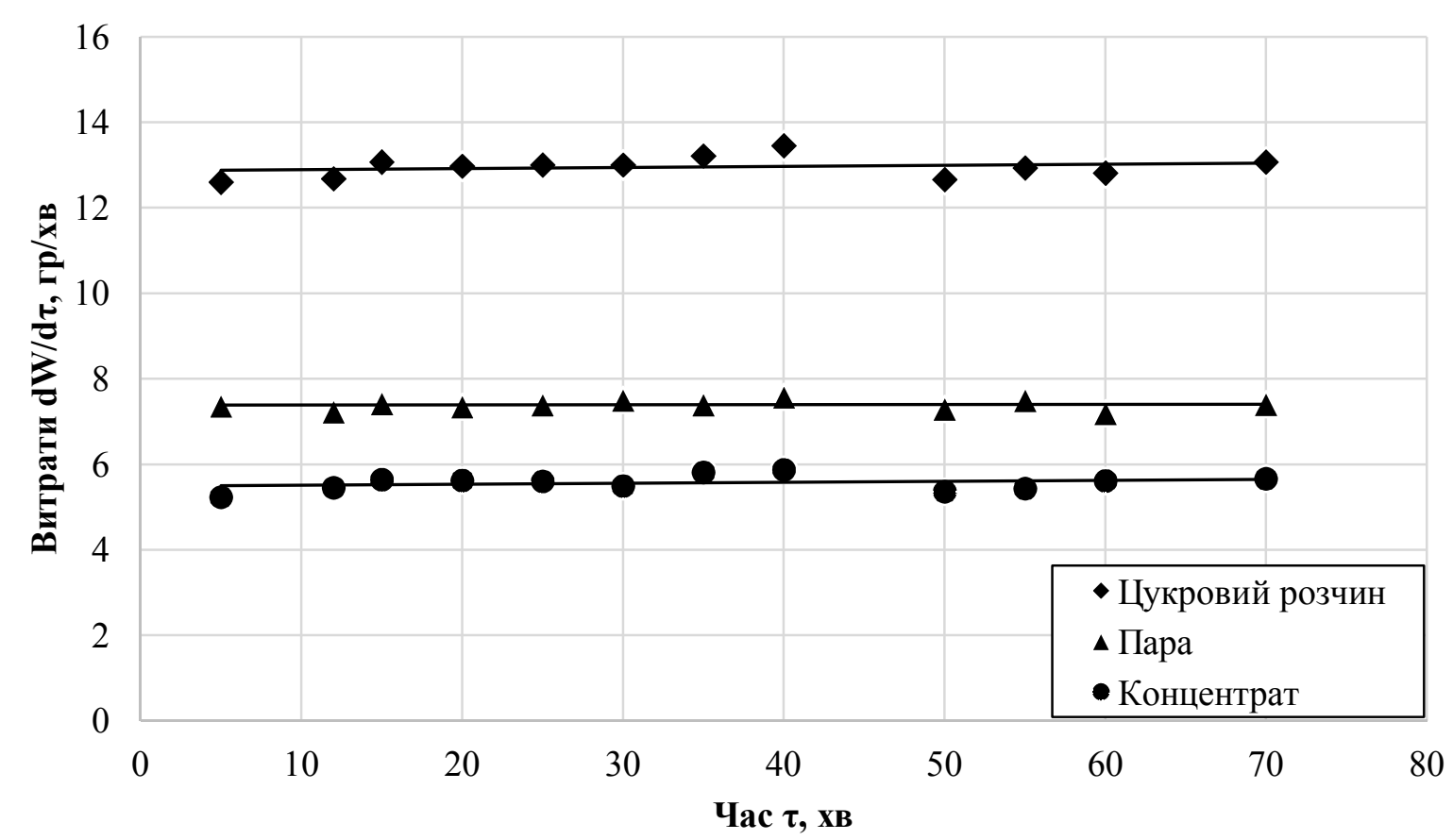

Рис. 3 - Витрати сировинних потоків при безперервному режимі роботи модуля

Виходячи з отриманої графічної залежності, можна зробити висновок, що узгодження матеріальних потоків було виконано успішно.

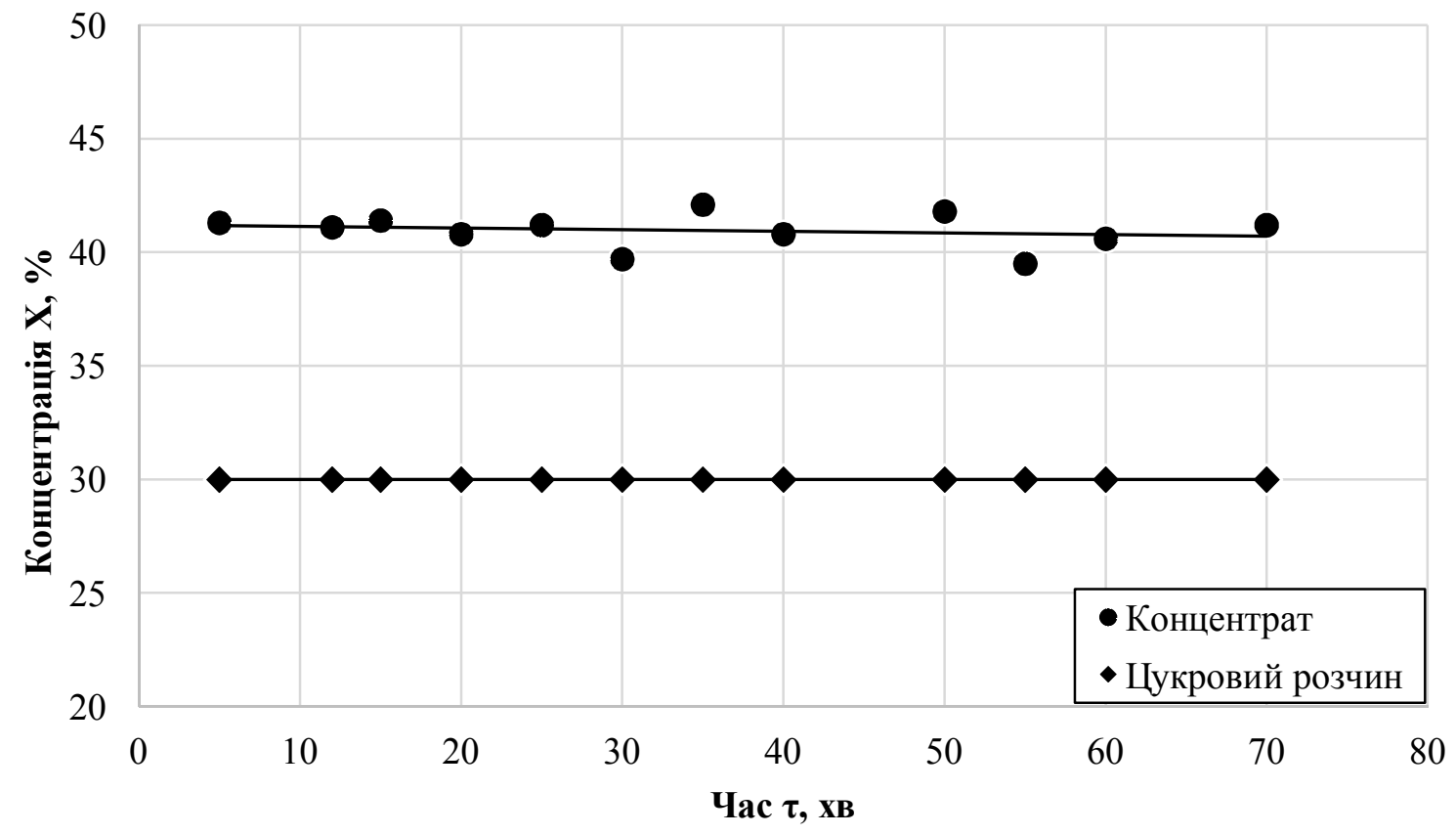

Рис. 4 - Концентрація продукту на вході і на виході модуля в режимі безперервної роботи

Підвищення кінцевої концентрації готового продукту майже на 50 \% (рис. 4) в режимі безперервної роботи в умовах вакууму є результатом успішного виконання поставленного завдання в даній роботі.

Висновок. Головний висновок за результатами випробувань - це підтвердження практичної працездатності розробленого експериментального зразка модуля, можливість стабільного підвищення концентрації продукту на одному ступені на 10-30brix в залежності від концентрації сировини на вході. Наведені залежності (рис. 3,4$)$ є базою для організації роботи модуля в умовах виробництва.

\section{References}

1. Peng, J., Bi, J., Yi, J., Allaf, K., Besombes, C., Jin, X., Wu, X., Lyu, J., Asghar Ali, M. N. H. (2019). Apple juice concentrate impregnation enhances nutritional and textural attributes of the instant controlled pressure drop (DIC) dried carrot chips. Journal of the Science of Food and Agriculture. doi:10.1002/jsfa.9898 
2. Jiménez-Sánchez, C., Lozano-Sánchez, J., Segura-Carretero, A., \& Fernández-Gutiérrez, A. (2015). Alternatives to conventional thermal treatments in fruit-juice processing. Part 2: Effect on composition, phytochemical content, and physicochemical, rheological, and organoleptic properties of fruit juices. Critical Reviews in Food Science and Nutrition, 57(3), 637-652. doi:10.1080/10408398.2014.914019

3. Brunda, G., Kavyashree, U., Shetty, S. S., Sharma, K. (2021). Comparative study of not from concentrate and reconstituted from concentrate of pomegranate juices on nutritional and sensory profile. Food Science and Technology International. doi: 10.1177/10820132211003707

4. Salehi, F. (2020). Physicochemical characteristics and rheological behaviour of some fruit juices and their concentrates. Journal of Food Measurement and Characterization. doi:10.1007/s11694-020-00495-0

5. Putnik, P., Pavlić, B., Šojić, B., Zavadlav, S., Žuntar, I., Kao, L., Kitonić, D., Kovačević, D. B. (2020). Innovative Hurdle Technologies for the Preservation of Functional Fruit Juices. Foods, 9(6), 699. doi:10.3390/foods9060699

6. Lorenzoni, G., Minto, C., Vecchio, M. G., Zec, S., Paolin, I., Lamprecht, M., Mestroni, L., Gregori, D. (2019). Fruit and Vegetable Concentrate Supplementation and Cardiovascular Health: A Systematic Review from a Public Health Perspective. Journal of Clinical Medicine, 8(11), 1914. doi:10.3390/jcm8111914

7. Burdo, O. G., Terziev, S. G., Gavrilov, A. V., Sirotyuk, I. V., Shcherbich, M. V. (2020). Sistema innovatsyonnyh energotekhnologiy obezvozhivaniya pishchevogo syr'ya [System of innovative energy technologies for dehydration of food raw materials]. Problemele Energeticii Regionale, 2(46), 93-107 (in Russian). doi: 10.5281/zenodo.3898317

8. Potapov, V. O., Evlash, V. V., Pedorich, I. P. (2018). Analiz sirovini, protsesiv ta obladnannya dlya otrimannya kharchovikh poroshkiv [Analysis of raw materials, processes and equipment for the production of food powders]. Zbirnik naukovikh prats` XVII mizhnarodnoyi naukovoyi konferentsiyi Udoskonalennya protsesiv i obladnannya kharchovikh i khimichnikh virobnitstv 3-8 veresnya Odesa. 149-152 (in Russian).

9. Chua, L. S., Leong, C. Y. (2020). Effects of microwave heating on quality attributes of pineapple juice. Journal of Food Processing and Preservation. doi:10.1111/jfpp.14786

10. Kumar, A., Shrivastava, S. L. (2019). Temperature, concentration, and frequency dependent dielectric properties of pineapple juice relevant to its concentration by microwave energy. Journal of Food Process Engineering, e13013. doi:10.1111/jfpe.13013

11. Bozkir, H., \& Baysal, T. (2017). Concentration of apple juice using a vacuum microwave evaporator as a novel technique: Determination of quality characteristics. Journal of Food Process Engineering, 40(5), e12535. doi: $10.1111 /$ jfpe. 12535

12. Asghar, M. T., Yusof, Y. A., Noriznan Mokhtar, M., Yaacob, M. E., Ghazali, H. M., Varith, J., Chang, L. S., Manaf, Y. N. (2020). Processing of Coconut Sap into Sugar Syrup using Rotary Evaporation, Microwave and Open-Heat Evaporation Techniques. Journal of the Science of Food and Agriculture. doi:10.1002/jsfa.10446

13. Dinçer, C., Çam, I. B., Torun, M. Gülmez, H. B., Topuz, A. (2019). Mathematical modeling of concentrations of grape, pomegranate and black carrot juices by various methods. The Journal of Food, 44(6). 1092-1105. doi: 10.15237/gida.GD19080

14. Burdo, O. G., Trishyn, F. A., Terziev, S G., Gavrilov S. G., Sirotyuk, I. V. (2021). Electrodynamic Processes as an Effective Solution of Food Industry Problems. Surf. Engin. Appl. Electrochem., 57, 330-344. doi: 10.3103/S1068375521030030

15. Burdo, O. G., Burdo A. K., Sirotyuk, I. V., Pour D. R. (2017). Tekhnologii selektivnogo podvoda energii pri vyparivanii pishchevykh rastvorov [Technologies of selective energy supply during evaporation of food solutions]. Problemele Energeticii Regionale, 1(33), 100-109 (in Russian). doi: 10.5281/zenodo.1193622

\title{
RESEARCH OF A MICROWAVE VACUUM EVAPORATOR MODULE OF THE CONTINUOUS ACTION
}

\author{
Sirotyuk I.V., postgraduate student \\ Odessa National Academy of Food Technologies, Odessa, Ukraine
}

The analysis of studies of the microwave technologies influence on the evaporation process is carried out. The main advantages of using electromagnetic action on raw materials during evaporation along with traditional technologies for concentrating food solutions are highlighted. One of the main disadvantages of the existing research stands of evaporators with electromagnetic energy supply, namely the frequency of action, is highlighted. The main problems that hinder the organization of the evaporation process in a continuous mode under conditions of volumetric energy and vacuum supply are determined. Based on the analysis of these problems, a design of a microwave vacuum-evaporation module has been proposed, which makes it possible to ensure continuous operation without breaking the tightness of the system and in the absence of microwave field leakage during the entire concentration process. The main task of this work was to conduct experimental studies of the developed module in continuous operation. The experiments were carried out using a sugar solution as an example. The concentrations of the incom- 
ing feedstock and the finished product discharged throughout the entire process were $30^{\circ}$ brix and $40-42^{\circ}$ brix, respectively. The pressure in the system during the tests of the module remained unchanged and was within $0.01 \mathrm{MPa}$. Based on the results of experimental studies, it can be argued about the operability of the considered design of a microwave vacuum-evaporation module of continuous operation and about the possibility of designing and implementing its semi-industrial sample. By using the method of assembling such modules, it is possible to design a multistage evaporator unit, which in turn makes it possible to obtain a finished product of any final concentration of dry substances without loss of quality. In addition, this design is quite easy to maintain due to the independence of each module.

Key words: evaporation, concentration, microwave technologies, modeling, heat and mass transfer.

\section{Список використаної літератури}

1. Peng, J., Bi, J., Yi, J., Allaf, K., Besombes, C., Jin, X., Wu, X., Lyu, J., Asghar Ali, M. N. H. Apple juice concentrate impregnation enhances nutritional and textural attributes of the instant controlled pressure drop (DIC) dried carrot chips. Journal of the Science of Food and Agriculture. 2019. doi:10.1002/jsfa.9898

2. Jiménez-Sánchez C., Lozano-Sánchez J., Segura-Carretero A., Fernández-Gutiérrez A. Alternatives to conventional thermal treatments in fruit-juice processing. Part 2: Effect on composition, phytochemical content, and physicochemical, rheological, and organoleptic properties of fruit juices. Critical Reviews in Food Science and Nutrition. 2015. Vol. 57. № 3. P. 637-652. doi:10.1080/10408398.2014.914019

3. Brunda G., Kavyashree U., Shetty S. S., Sharma K. Comparative study of not from concentrate and reconstituted from concentrate of pomegranate juices on nutritional and sensory profile. Food Science and Technology International. 2021. doi: 10.1177/10820132211003707

4. Salehi, F. Physicochemical characteristics and rheological behaviour of some fruit juices and their concentrates. Journal of Food Measurement and Characterization. 2020. doi:10.1007/s11694-020-00495-0

5. Putnik, P., Pavlić, B., Šojić, B., Zavadlav, S., Žuntar, I., Kao, L., Kitonić, D., Kovačević, D. B. Innovative Hurdle Technologies for the Preservation of Functional Fruit Juices. Foods, 2020. Vol. 9. № 6. P. 699. doi:10.3390/foods9060699

6. Lorenzoni G., Minto C., Vecchio M. G., Zec S., Paolin I., Lamprecht M., Mestroni L., Gregori D. Fruit and Vegetable Concentrate Supplementation and Cardiovascular Health: A Systematic Review from a Public Health Perspective. Journal of Clinical Medicine. 2019. Vol. 11. № 8. doi:10.3390/jcm8111914

7. Бурдо О. Г., Терзиев С. Г., Гаврилов А. В., Сиротюк И. В., Щербич М. В. Система инновационных энерготехнологий обезвоживания пищевого сырья. Problemele Energeticii Regionale. 2020. Т. 46. № 2. С. 93 107. doi: $10.5281 /$ zenodo.3898317

8. Потапов В. О., Свлаш В. В., Педорич І. П. Аналіз сировини, процесів та обладнання для отримання харчових порошків. Удосконалення прочесів і обладнання харчових іхімічних виробниитв : зб. наук. праць XVII міжнар. наук. конф., м. Одеса, 3-8 вересня 2018. Одеса, 2018. С. 149-152.

9. Chua, L. S., Leong C. Y. Effects of microwave heating on quality attributes of pineapple juice. Journal of Food Processing and Preservation. 2020. doi:10.1111/jfpp.14786

10. Kumar A., Shrivastava S. L. Temperature, concentration, and frequency dependent dielectric properties of pineapple juice relevant to its concentration by microwave energy. Journal of Food Process Engineering. 2019. e13013. doi:10.1111/jfpe.13013

11. Bozkir H., Baysal T. Concentration of apple juice using a vacuum microwave evaporator as a novel technique: Determination of quality characteristics. Journal of Food Process Engineering. 2017. Vol. 40. № 5. e12535. doi: $10.1111 /$ jfpe. 12535

12. Asghar M. T., Yusof Y. A., Noriznan Mokhtar M., Yaacob M. E., Ghazali H. M., Varith J., Chang L. S., Manaf Y. N. Processing of Coconut Sap into Sugar Syrup using Rotary Evaporation, Microwave and Open-Heat Evaporation Techniques. Journal of the Science of Food and Agriculture. 2020. doi:10.1002/jsfa.10446

13. Dinçer C., Çam I. B., Torun M. Gülmez H. B., Topuz A. Mathematical modeling of concentrations of grape, pomegranate and black carrot juices by various methods. The Journal of Food. 2019. Vol. 44. №6. P. 10921105. doi: 10.15237/gida.GD19080

14. Burdo O. G., Trishyn F. A., Terziev S. G., Gavrilov S. G., Sirotyuk I. V. Electrodynamic Processes as an Effective Solution of Food Industry Problems. Surf. Engin. Appl. Electrochem. 2021. Vol. 57. P. 330-344. doi: 10.3103/S1068375521030030

15. Бурдо О. Г., Бурдо А. К., Сиротюк И. В., Пур Д. Р. Технологии Селективного подвода энергии при выпаривании пищевых растворов. Problemele Energeticii Regionale. 2017. Т. 33. № 1. С. $100-109$. doi: $10.5281 /$ zenodo. 1193622

Отримано в редакцію 10.03.2021

Прийнято до друку 26.06.2021
Received 10.03.2021

Approved 26.06.2021 